\title{
LAYANAN GURU KELAS BAGI SISWA SLOW LEARNER DI \\ SEKOLAH INKLUSI (SD N BANGUNREJO 2 YOGYAKARTA)
}

\author{
Nurhidayah Eko Budi Utami
}

Fakultas Ilmu Tarbiyah dan Keguruan, UIN Sunan Kalijaga Yogyakarta

Email: nurhidayaahh@gmail.com

\begin{abstract}
ABSTRAK
SD N Bangunrejo 2 Yogyakarta merupakan sekolah yang berbasis inklusi. Sekolah tersebut memiliki beberapa golongan siswa berkebutuhan khusus, termasuk slow learner di dalamnya. Siswa slow learner yang ada di SD $\mathrm{N}$ Bangunrejo 2 Yogyakarta merupakan salah satu siswa berkebutuhan khusus dengan jumlah yang cukup besar. Siswa slow learner tersebut belajar berdampingan dengan siswa normal dan siswa dengan kebutuhan khusus lainnya. Hal tersebut menjadikan peneliti ingin mencari tahu lebih lanjut mengenai layanan yang diberikan guru kelas bagi siswa slow learner di sekolah tersebut. Penelitian ini menggunakan metode penelitian kualitatif. Penelitian ini digunakan untuk menggali data tentang layanan yang diberikan guru kelas kepada siswa slow learner di sekolah inklusi. Objek dari penelitian ini adalah layanan guru kelas bagi siswa slow learner di sekolah inklusi. Sedangkan subjeknya adalah guru kelas yang berjumlah lima orang. Untuk menjawab permasalahan tersebut peneliti menggunakan metode pengumpulan data berupa wawancara, observasi, dokumentasi, dan teknik triangulasi data. Hasil penelitian yang diperoleh menunjukkan bahwa pemberian layanan oleh guru kelas bagi siswa slow learner di SD N Bangunrejo 2 Yogyakarta yang mencakup 3 hal, yaitu modifikasi alokasi waktu, modifikasi isi atau materi, dan modifikasi proses pembelajaran sudah terlaksana. Selain itu, ditemukan juga adanya penggunaan media dalam proses pembelajaran. Layanan yang diberikan oleh guru kelas belum terlaksana dengan maksimal, belum sepenuhnya memenuhi kebutuhan siswa slow learner. Selain itu, belum adanya program pebelajaran individu bagi siswa slow learner.
\end{abstract}




\title{
Kata Kunci: Layanan Guru Kelas, Pendidikan Dasar, dan Slow Learner.
}

\begin{abstract}
SD N Bangunrejo 2 Yogyakarta is an inclusive school. The school has several classes of students with special needs, including slow learners in it. Slow learner students in SD N Bangunrejo 2 Yogyakarta are one of the students with special needs with a fairly large number. The slow learner learns alongside normal students and students with other special needs. This makes the researchers want to find out more about the services provided by class teachers for slow learner students at the school. This study used qualitative research methods. This study was used to explore data about services provided by classroom teachers to slow learner students in inclusive schools. The object of this thesis research is the classroom teacher service for slow learner students in inclusive schools. While the subject is a class teacher of five people. To answer these problems researchers used data collection methods in the form of interviews, observation, documentation, and data triangulation techniques. The results obtained showed that the provision of services by classroom teachers for students slow learner at SD $N$ Bangunrejo 2 Yogyakarta which included 3 things, namely modification of time allocation, modification of content or material, and modification of the learning process had been carried out. In addition, there is also the use of media in the learning process. The services provided by the class teacher have not been carried out optimally, not yet fully meeting the needs of students slow learner. In addition, there is no individual learning program for students who are slow learners.
\end{abstract}

\section{Keywords: Classroom Teacher Services, Basic Education, and Slow Learner.}

\section{A. PENDAHULUAN}

Slow learner merupakan salah satu jenis ketunaan yang banyak dihadapi. Secara kasat mata, anak yang terdeteksi mengalami slow learner nampak seperti anak seusianya pada umumnya. Slow learner adalah anak yang memiliki prestasi belajar 
rendah di bawah rata-rata anak pada umumnya) pada salah satu atau seluruh area akademik, tapi tidak tergolong anak yang mempunyai keterbelakangan mental. Skor tes IQ anak slow learner menunjukkan antara 70 dan $90 .{ }^{1}$

Banyak anak slow learner yang tidak teridentifikasi ketunaannya kemudian bersekolah di sekolah formal reguler. Mereka diperlakukan sama dengan siswa normal lain, hingga tidak jarang label bodoh diberikan. Anak slow learner juga bukan penyandang kebutuhan khusus yang harus diberikan pendidikan luar biasa. Anak slow learner seharusnya diberi pendidikan formal dengan kebutuhan inklusi, ataupun yang berbasis inklusi.

Yusuf dalam Khayati menjelaskan tentang anak slow learner atau lamban belajar merupakan anak dengan intelegensi sedikit di bawah rata-rata (IQ 70-90) yang memerlukan layanan pendidikan khusus agar mereka mampu memahami pelajaran dengan baik. Sementara, Suparno dalam Khayati menyebutkan bahwa layanan pendidikan bagi anak berkebutuhan khusus merupakan usaha untuk memenuhi kebutuhan anak-anak berkebutuhan khusus yang memiliki keunikan tersendiri dalam jenis dan karakteristiknya yang membedakan dengan anak-anak normal pada umumnya. $^{2}$

Ketika berada di sekolah inklusi, penerimaan diri anak slow learner akan dirinya semakin besar. Mereka tidak lagi menarik diri dari pergaulan karena mereka merasa diberi perlakuan yang sama. Lebih utamanya, mereka tidak diberi label bodoh. Guru menganggap semua siswa di sekolah inklusi sama, antara siswa yang normal maupun siswa yang berkebutuhan khusus. SD N Bangunrejo 2 adalah salah satu Sekolah Dasar di Yogyakarta yang menyelenggarakan pendidikan inklusi. Pendidikan inklusi bisa dikatakan sebagai pendidikan dengan sistem layanan pendidikan yang mengikutsertakan anak berkebutuhan khusus belajar bersama dengan anak sebayanya di sekolah umum.

SD N Bangunrejo 2 merupakan salah satu sekolah yang ditunjuk oleh pemerintah untuk menyelenggarakan pendidikan inklusi. Penyelengaraan pendidikan inklusi di SD N Bangunrejo 2 Yogyakarta dimulai pada tahun 2011. Siswa yang diterima

1. Nur Khabibah, "Penanganan Instruksional Bagi Anak Lambat Belajar (Slow Learner)," Jurnal Didaktika, Vol. 19, no. 1 Februari 2013,hlm. 1.

2. Abdiyatun Khayati, "Layanan Pendidikan Bagi Siswa Slow Learner Oleh Guru di Kelas III,” Jurnal Pendidikan Guru Sekolah Dasar, Edisi 25 Tahun ke-5, 2016, hl, 2.336. 
adalah siswa yang mengalami permasalahan belajar seperti kesulitan belajar dan slow learner, permasalahan emosi dan perilaku, serta tunadaksa. ${ }^{3}$

Berdasarkan data yang diberikan pihak sekolah, bahwasannya siswa yang tergolong berkebutuhan khusus hampir setengah total dari keseluruhan jumlah siswa. Jumlah seluruh siswa yang bersekolah di SD Nergeri Bangunrejo 2 adalah 92 siswa, sedangkan 63 siswa merupakan siswa berkebutuhan khusus. Dari enam kelas yang ada, jenis ketunaan yang disandang siswa ABK yang ada di SD Negeri Bangunrejo 2 terdapat bermacam-macam, yaitu: ${ }^{4}$

Tabel 1.1

Daftar Jenis Ketunaan ABK di SD N Bangunrejo 2 Yogyakarta

\begin{tabular}{|l|c|}
\hline \multicolumn{1}{|c|}{ Jenis Ketunaan } & Jumlah Siswa \\
\hline Slow learner & 23 \\
\hline Autis & 1 \\
\hline Tunagrahita Ringan & 22 \\
\hline Tunagrahita Sedang & 2 \\
\hline Tunadaksa & 1 \\
\hline Kesulitan Belajar & 7 \\
\hline Tunaganda & 4 \\
\hline Gangguan Kecemasan & 2 \\
\hline Tunarungu Tipe Ringan & 1 \\
\hline Total ABK & 63 \\
\hline
\end{tabular}

Menurut data yang ada, siswa slow learner di SD N Bangunrejo 2 terdapat 23 siswa. Kedua puluh satu siswa tersebut tersebar dari kelas 1 hingga kelas 6. Selama proses pembelajaran, siswa slow learner dibimbing oleh guru kelas masing-masing. Guru pembimbing khusus yang ada tidak memadai, hanya terdapat 1 orang guru pendamping khusus yang hanya datang dua kali dalam seminggu. Maka dari itu

3. Wawancara dengan Kepala Sekolah pada 18 Januari 2018.

4. Studi dokumen SD N Bangunrejo 2 Yogyakarta. 
ketika di kelas, selain menjadi guru kelas, guru kelas juga berperan sebagai guru pendamping bagi siswa inklusi khususnya siswa slow learner.

Berdasarkan analisis di atas, masalah yang diangkat dalam penelitian ini sebagai berikut: "Bagaimana Layanan yang Diberikan Guru bagi Siswa Slow Learner di Sekolah Inklusi (SD N Bangunrejo 2 Yogyakarta)?" Tujuan yang ingin dicapai dalam penelitian ini adalah untuk mengetahui layanan yang diberikan oleh guru kelas kepada siswa slow learner di sekolah inklusi (SD N Bangunrejo 2 Yogyakarta).

\section{B. ANAK LAMBAN BELAJAR}

Lamban belajar adalah kesulitan belajar yang disebabkan anak sangat lamban dalam proses belajarnya, sehingga setiap melakukan kegiatan belajar membutuhkan waktu yang lebih lama dibandingkan dengan anak lain yang memiliki tingkat potensi intelektual sama. ${ }^{5}$ Lamban belajar adalah anak yang memiliki potensi intelektual sedikit di bawah anak normal, tetapi tidak termasuk anak tunagrahita (biasanya memiliki IQ sekitar 80-85). ${ }^{6}$

Dalam beberapa hal, anak lamban belajar mengalami hambatan atau keterlambatan berpikir, merespon rangsangan dan kemampuan untuk beradaptasi, tetapi lebih baik dibanding dengan yang tunagrahita. Mereka membutuhkan waktu belajar lebih lama dibanding dengan sebayanya. Sehingga mereka memerlukan layanan pendidikan khusus. ${ }^{7}$

\section{FAKTOR-FAKTOR PENYEBAB ANAK LAMBAN BELAJAR}

Ada banyak faktor yang dapat menyebabkan anak lamban belajar. Beberapa ahli mengemukakan faktor penyebab anak lamban belajar adalah sebagai berikut: ${ }^{8}$

1. Kemiskinan

Kemiskinan adalah kondisi sosial ekonomi seseorang atau sekelompok orang yang tidak terpenuhinya hak-hak dasarnya untuk mempertahankan dan megembangkan kehidupan yang bermartabat.

5. Sugihartono, Psikologi Pendidikan (Yogyakarta: UNY Press, 2007), hlm. 151.

6. Abdul dkk, Pendidikan Anak Berkebutuhan Khusus Secara Inklusif (Surakarta: Universitas Sebelas Maret, 2009), hlm. 34.

7. Ibid.

8. Lokanadha Reddy G, Slow Learner: Their Psychology and Instruction (New Delhi: Discovery Publishing House, 2006), hlm. 11-15. 
2. Kecerdasan Orang Tua

Orang tua yang tidak berkesempatan mendapat pendidikan yang layak dapat menyebabkan anak lamban belajar. Hal tersebut karena biasanya orang tua kurang memperhatikan perkembangan intelektual anak.

3. Jumlah Anggota Keluarga

Jumlah anggota keluarga yang sebaiknya dimiliki di Indonesia adalah 4 orang. Yaitu ayah, ibu, dan dua orang anak. Hal tersebut sesuai dengan Norma Keluarga Kecil Bahagia dan Sejahtera (NKKBS). ${ }^{9}$

4. Faktor Emosi

Anak lamban belajar mengalami masalah emosi berat dan berkepanjangan yang menghambat proses pembelajaran. Masalah emosi ini menyebabkan anak lamban belajar memiliki prestasi belajar rendah, hubungan interpersonal yang buruk, dan konsep diri yang rendah.

5. Faktor pribadi

Faktor-faktor pribadi yang dapat menyebabkan anak lamban belajar meliputi: (1) kelainan fisik, (2) kondisi tubuh yang terserang penyakit, (3) mengalami gangguan penglihatan, pendengaran, dan berbicara, (4) ketidakhadiran di sekolah; dan (5) kurang percaya diri.

\section{KARAKTERISTIK SISWA LAMBAN BELAJAR}

Anak lamban belajar mempunyai karakteristik tertentu yang membedakannya dari anak normal. Karakteristik anak lamban belajar ditinjau dari faktor-faktor penyebabnya, antara lain: ${ }^{10}$

1. Keterbatasan Kapasitas Kognitif

Keterbatasan kapasitas kognitif membuat anak lamban belajar mengalami hambatan dalam proses pembelajaran, meliputi: (a) tidak berhasil mengatasi situasi belajar dan berpikir abstrak; (b) mengalami kesulitan dalam operasi berpikir kompleks; (c) proses pengembangan konsep atau generalisasi ide yang mendasari tugas sekolah, khususnya bahasa dan matematika, rendah; dan (d) tidak dapat menggunakan dengan baik strategi kognitif yang penting untuk proses retensi.

9. Sehmawati, "Kajian Program KB 2 Anak Cukup terhadap Nilai Anak dengan Keinginan Wanita Menambah Anak," Jurnak Kesehatan Ibu dan Anak, Vol. 1, no. 1, Desember 2006, hlm. 43.

10. G, Slow Learner: Their Psychology and Instruction, hlm. 6-8. 
2. Memori atau Daya Ingat Rendah

Kurangnya perhatian terhadap informasi yang disampaikan adalah salah satu faktor penyebab anak lamban belajar mempunyai daya ingat yang rendah. Anak lamban belajar tidak dapat menyimpan informasi dalam jangka panjang dan memanggil kembali ketika dibutuhkan.

3. Gangguan dan Kurang Konsentrasi

Jangkauan perhatian anak lamban belajar relatif pendek dan daya konsentrasinya rendah. Anak lamban belajar tidak dapat berkonsentrasi dalam pembelajaran yang disampaikan secara verbal lebih dari tiga puluh menit.

4. Ketidakmampuan Mengungkapkan Ide

Kesulitan dalam menemukan dan mengombinasikan kata, ketidakdewasaan emosi, dan sifat pemalu membuat anak lamban belajar tidak mampu berekspresi atau mengungkapkan ide. Anak lamban belajar lebihs sering menggunakan bahasa tubuh daripada bahasa lisan. Selain itu, kemampuan anak lamban belajar dalam mengingat pesan dan mendengarkan instruksi rendah.

\section{E. BENTUK-BENTUK LAMBAN BELAJAR}

Belajar merupakan suatu proses dari seorang individu yang berusaha untuk mencapai tujuan belajar atau hasil belajar dalam proses atau aktifitas belajar, misalnya dalam hal menghafal, berhitung, membaca, dan menulis terdapat kendala seperti yang dialami oleh anak lamban belajar. Kendala secara umum yang dihadapi oleh anak lamban belajar dapat diuraikan sebagai berikut: ${ }^{11}$

1. Aspek Kognitif

Meliputi masalah-masalah dalam hal kemampuan berbicara, membaca, menulis, mendengarkan, berpikir, dan matematis semuanya merupakan penekanan terhadap aspek akademik atau kognitif.

2. Aspek Bahasa

Bahasa reseptif adalah kecakapan menerima dan memahammi bahasa. Bahasa ekspresif adalah kemampuan mengekspresikan diri secara verbal. Dalam proses belajar kemampuan bahasa merupakan alat untuk memahami dan menyatakan

11. Sutjihati Soemantri T, Psikologi Anak Luar Biasa, (Bandung: PT. Refika Aditama, 2006), hlm. 20 . 
pikiran. Masalah kemampuan berbahasa akan berpengaruh signifikan terhadap kegagalan belajar.

3. Aspek Motorik

Keterampilan motorik perseptual ini sangat diperlukan untuk mengembangkan keterampilan meniru rancangan atau pola. Kemampuan ini sangat diperlukan untuk menggambar, menulis, atau menggunakan gunting. Keterampilan tersebut sangat memerlukan koordinasi yang baik antara tangan dan mata.

4. Aspek Sosial dan Emosi

Kelabilan emosi dan keimpulsifan, kelabilan emosional ditunjukkan oleh sering berubahnya suasana hati dan tempramen. Keimpulsifan merujuk pada lemahnya pengendalian terhadap dorongan-dorongan berbuat.

\section{F. LAYANAN GURU KELAS BAGI SISWA LAMBAN BELAJAR}

Slow learner merupakan salah satu anak berkebutuhan khusus (ABK) yang tidak dapat dikenali dari penampilan fisiknya namun membutuhkan layanan pendidikan yang bersifat khusus, yaitu layanan yang berbentuk program pendidikan khusus yang bertujuan untuk membantu mengurangi keterbatasanya dalam hidup bermasyarakat. Sebagai manusia, setiap anak yang memiliki kemampuan di bawah rata-rata memiliki hak dan layakn untuk bersekolah sama seperti saudara lainnya yang mempunyai kemampuan normal atau di atas rata-rata. ${ }^{12}$ Warga negara yang memiliki kelainan fisik, mental, intelektual, emosional dan sosial berhak memperoleh pendidikan khusus. ${ }^{13}$

Slow learner merupakan ABK yang mengalami keterlambatan dalam pembelajaran. Sehubungan dengan hal tersebut, maka guru perlu memberikan layanan secara optimal bagi semua peserta didik termasuk anak lamban belajar karena dalam jenjang sekolah umum terkadang ditemui peserta didik yang termasuk anak lamban belajar yang memerlukan perhatian dan layanan pendidikan yang sesuai dengan kondisi dan kebutuhannya. ${ }^{14}$

12. Nur Khabibah, "Penanganan Instruksional Bagi Anak Lambat Belajar (Slow Learner)," Jurnal Didaktika, Vol. 19, no. 2, Februari 2013, hlm. 1.

13. UUSPN Pasal 5 ayat 2.

14. Nur Khabibah, "Penanganan Instruksional Bagi Anak Lambat Belajar (Slow Learner)," Jurnal Didaktika, Vol. 19, no. 2, Februari 2013,hlm. 3. 
Berikut layanan dalam hal pengembangan kurikulum yang dapat diberikan guru pada siswa lamban belajar: ${ }^{15}$

1. Modifikasi Alokasi Waktu

Misalnya materi pelajaran tertentu dalam kurikulum reguler diperkirakan alokasinya selama enam jam. Untuk anak berkebutuhan khusus yang memiliki intelegensi di bawah normal (lamban belajar) dapat dimodifikasi menjadi 10 jam atau lebih.

2. Modifikasi Isi atau Materi

Untuk anak lamban belajar, materi dalam kurikulum reguler dapat dikurangi atau diturunkan tingkat kesulitanya seperlunya, atau bahkan dihilangkan bagian tertentu.

3. Modifikasi Proses Belajar Mengajar

Guru hendaknya tidak monoton dalam mengajar sehingga hanya akan menguntungkan anak yang memiliki tipe belajar tertentu saja.

Beberapa strategi pengajaran dapat dilakukan dalam membantu anak lamban belajar atau slow learner dibanding dengan teman-teman sekelasnya, yaitu:

1. Selalu memulai pelajaran dengan review atau mengulang materi sebelumnya untuk mengaitkan materi pelajaran yang akan disampaikan.

2. Menggunakan bahasa sederhana namun jelas dengan perlahan.

3. Melakukan tas analysis atau analisa tugas jika akan memberikan tugas atau pekerjaan rumah (PR).

4. Memberi tugas yang lebih sederhana atau lebih sedikit kepada siswa slow learner dibanding teman-temannya untuk menghindari frustasi.

5. Melakukan pengulangan materi jika menyampaikan materi pelajaran, akan mendapatkan hasil yang lebih optimal jika disampaikan secara individual.

6. Melakukan pembelajaran secara kooperatif karena anak lamban belajar atau slow learner tidak menyenangi kompetitif.

7. Memberikan pemahaman konsep walau membutuhkan waktu cukup lama dibandingkan dengan menghafal konsep karena akan membuat anak lamban belajar atau slow learner putus asa.

15. Nunung Apriyanto, Seluk Beluk Tunagrahita dan Strategi Pembelajarannya (Yogyakarta: Javalitera, 2012), hlm. 84. 
8. Menggunakan multi pendekatan dan motivasi belajar.

9. Memakai desain pembelajaran yang menempatkan siswa dalam konteks pembelajaran yang "tidak pernah gagal" untuk menghindari perasaan tidak berdaya.

\section{G. HASIL PENELITIAN DAN PEMBAHASAN}

Penelitian terhadap layanan guru kelas bagi siswa slow learner dilaksanakan di sekolah inklusi SD N Bangunrejo 2 Yogyakarta di kelas I-V. Di kelima kelas tersebut terdapat anak berkebutuhan khusus yang terasesmen anak slow learner. Kelima guru kelas yang menjadi subjek penelitian menghadapi kondisi yang berbeda-beda antara satu dengan yang lainnya dalam merancang dan menerapkan strategi pembelajaran anak slow learner. Kondisi tersebut meliputi jumlah siswa normal di kelas, jumlah anak berkebutuhan khusus di kelas, dan jumlah anak slow learner.

Berdasarkan data hasil wawancara, hasil observasi, dan hasil dokumentasi, maka hasil penelitian terhadap layanan yang diberikan guru kepada anak slow learner di SD N Bangunrejo 2 Yogyakarta adalah sebagai berikut:

1. Modifikasi Alokasi Waktu

Hasil penelitian menunjukkan bahwa kelima guru kelas (guru kelas I-V) melakukan modifikasi alokasi waktu dalam proses pembelajaran. Namun, tiap guru mempunyai cara yang berbeda dalam melakukan modifikasi alokasi waktu. Perbedaan ini bergantung pada kondisi dan tingkat kelas siswa slow learner yang ada.

Kelima guru kelas memiliki strategi masing-masing dalam memberikan modifikasi alokasi waktu pada saat anak lamban belajar mengerjakan soal, tes, maupun tugas lainnya. Guru kelas I memberikan modifikasi waktu untuk siswa slow learner berupa tambahan waktu saat siswa mengerjakan latihan soal di kelas, ulangan harian, maupun ujian akhir. Ketika pengerjaan latihan soal di dalam kelas, guru memberikan tambahan waktu untuk siswa slow learner hingga mereka selesai mengerjakan soal. Jika siswa reguler lebih cepat dalam mengerjakan soal, guru kelas akan meminta siswa reguler untuk membaca atau mengerjakan bagian selanjutnya. Selama proses penambahan waktu, guru kelas I tidak diam saja menunggu siswa slow learner selesai mengerjakan. Beliau juga tak henti mengingatkan agar siswa slow learner segera menyelesaikan pekerjaannya, juga memberikan bantuan jika siswa slow learner menemui kesulitan pengerjaan. 
Saat ulangan harian maupun ujian akhir, guru kelas I juga memberikan tambahan waktu pengerjaan kepada siswa slow learner. Hal tersebut dikarenakan, tanpa diberikannya perpanjangan waktu, sisa slow learner hanya akan mengerjakan soal dalam jumlah sedikit. Sedangkan siswa reguler mampu mengerjakan soal yang lebih banyak dengan waktu yang lebih sedikit. ${ }^{16}$

Guru kelas II memberikan modifikasi alokasi waktu yang berbeda dengan guru kelas I. Saat pengerjaan latihan soal di kelas, guru kelas II tidak memberikan tambahan waktu. Guru kelas II menganggap pemberian tambahan waktu untuk anak slow learner percuma, karena selama apapun waktu yang diberikan saat jam pelajaran, anak slow learner tersebut tetap tidak selesai.

Saat pengerjaan soal latihan di kelas, waktu yang diberikan untuk siswa reguler dan siswa slow learner sama. Jika waktu yang diberikan oleh guru telah habis, guru tidak memberikan perpanjangan waktu, melainkan akan langsung mengoreksi hasil pekerjaan atau meminta siswa mengumpulkan.

Guru kelas II tidak memberikan tambahan waktu ketika pengerjaan latihan soal di kelas karena anak-anak slow learner yang ada di kelas II sangat sulit dan lama jika diminta mengerjakan soal. Terkadang, siswa slow learner di kelas II untuk sekedar menuliskan soal saja sangat lama, belum ditambah waktu pengerjaannya. Oleh karena itu guru kelas II selalu melanjutkan pembelajaran jika banyak siswa yang sudah selesai mengerjakan soal. Guru kelas II tidak mau mengorbankan siswa reguler lain yang sudah bisa dengan menghabiskan waktu untuk fokus ke anak slow learner yang ada di kelasnya. Sebagai gantinya, guru kelas II memberikan tambahan waktu untuk mengerjakan soal atau menjelaskan suatu materi kepada anak slow learner saat jam istirahat atau jam pulang sekolah. Hal tersebut dilakukan agar pembelajaran untuk siswa reguler tetap berjalan dan tidak terganggu. ${ }^{17}$

Guru kelas III memberikan perlakuan yang sama untuk siswa slow learner maupun siswa reguler yang ada di kelasnya. Saat mengerjakan latihan soal di kelas, guru memberikan tambahan waktu kepada siswa slow learner hingga siswa selesai mengerjakan. Namun biasanya, siswa slow learner tidak memakan waktu lama saat mengerjakan latihan soal. Hal tersebut karena saat pengerjaan latihan

16. Hasil Wawancara dengan Guru Kelas SD N Bangunrejo 2 Yogyakarta pada 10 mei 2018.

17. Hasil observasi di kelas II SD N Bangunrejo 2 Yogyakarta pada 14 Mei 2018. 
soal di kelas, siswa slow learner masih mendapat bantuan dari guru maupun siswa lain. Sehingga, mereka mampu mengerjakan soal dengan lebih cepat.

Berbeda dengan guru kelas I hingga III, guru kelas IV dan V tidak memberi modifikasi alokasi waktu untuk siswa slow learner. Guru kelas IV dan V memberikan porsi waktu yang sama untuk semua siswa di kelasnya. Hal tersebut dilakukan mengingat makin banyaknya materi yang harus dikuasai siswa, dan waktu yang terbatas. Sehingga menyebabkan guru kelas harus bisa membuat siswa mempelajari semua materi yang disampaikan. Jika ada perpanjangan waktu yang diberikan pada siswa slow learner di kelas IV atau V, hanya sekitar 5-10 menit agar dapat meneruskan kegiatan pembelajaran selanjutnya.

Ketika pengerjaan ulangan harian maupun ujian akhir pun, guru kelas IV dan $\mathrm{V}$ pun tidak memberikan perpanjangan waktu khusus. Guru lebih memanfaatkan waktu untuk memberikan pengulangan atau bimbingan kepada siswa slow learner.

2. Modifikasi Isi atau Materi

Dalam hal modifikasi isi atau materi, guru kelas perlu memperhatikan kondisi siswa slow learner juga materi yang akan disampaikan. Hasil penelitian untuk modifikasi isi atau materi pelajaran adalah sebagai berikut.

Kelima guru kelas menyampaikan materi secara urut, mulai dari yang paling mudah ke yang lebih sulit, dari konkret ke abstrak, dari sederhana ke kompleks, dan dari teori ke praktik. Dalam hal penyampaian materi, guru kelas memiliki toleransi khusus untuk anak slow learner. Materi yang disampaikan di kelas sama dengan materi yang telah ditentukan oleh kurikulum.

Penyampaian materi di kelas sama dengan materi yang telah ditentukan oleh kurikulum karena mengingat tidak semua siswa di kelas adalah siswa slow learner. Akan tetapi, jika ada anak slow learner yang masih belum memahami materi, guru kelas akan memberikan pengulangan baik secara klasikal maupun individual hingga siswa slow learner yang belum paham dapat segera memahami materi yang disampaikan. baik secara klasikal maupun individual hingga siswa slow learner yang belum paham dapat segera memahami materi yang disampaikan.

Ruang lingkup materi yang disampaikan untuk anak slow learner di kelas I-V sama dengan siswa reguler lain. Meskipun ruang lingkup yang disampaikan sama dengan siswa reguler lain, namun memiliki perbedaan pada tingkat kesulitan dan kedalaman materi. Tingkat kesulitan yang disampaikan lebih mudah karena guru lebih menekankan pada pengenalan dan pemahaman konsep pada anak. 


\section{Modifikasi Prosea Belajar Mengajar}

Pada tahap modifikasi proses belajar mengajar, terdapat beberapa aspek yang diperoleh dalam penelitian. Beberapa aspek tersebut dijelaskan seebagai berikut.

Tujuan pembelajaran yang ditetapkan oleh guru untuk siswa slow learner sama dengan tujuan pembelajaran yang ditetapkan untuk siswa reguler. Hanya saja, tingkat kesulitan materi disesuaikan dengan kemampuan siswa slow learner. Kriteria ketuntasan minimun (KKM) yang ditetapkan oleh guru kelas juga sama dengan siswa reguler. Namun, untuk siswa slow learner, guru memiliki tolok ukur tersendiri untuk siswa slow learner. Nilai 70 untuk siswa slow learner akan memiliki kualitas yang berbeda dengan nilai 70 pada siswa reguler. KKM untuk siswa slow learner dan siswa reguler ini ditetapkan sama karena guru memandang bahwa siswa slow learner masih dapat mengikuti pembelajaran seperti siswa lainnya, meskipun guru harus memberikan pengulangan-pengulangan secara terus menerus agar siswa slow learner menjadi paham.

Berdasarkan hasil penelitian yang diperoleh, strategi penyampaian materi yang efektif untuk kelas I hingga kelas V hampir semuanya sama. Hanya saja, untuk siswa kelas I, guru kelas lebih sering mengajak siswa slow learner belajar membaca agar siswa dapat membaca dengan lancar. Seperti yang telah dipaparkan sebelumnya, hal tersebut dilakukan karena masih banyak siswa kelas I yang belum dapat membaca dengan baik dan lancar.

Pada siswa slow learner yang ada di kelas II, guru kelas lebih sering memberikan latihan latihan kepada siswanya. Ada beberapa anak yang tidak bisa mengikuti proses pembelajaran di kelas, namun guru akan memberikan tambahan waktu di luar jam sekolah. Ketika di kelas, guru kelas II memperlakukan siswa slow learner dan siswa reguler dengan sama, tanpa membeda bedakan. Selain itu, latihan yang diberikan pada siswa pun diberikan secara klasikal. Dengan bobot soal yang sama.

Selanjutnya, untuk siswa kelas III, guru menggunakan strategi pembelajaran yang sama untuk semua siswa di kelas. Untuk siswa slow learner yang ada di kelas III, materi yang disampaikan sama dengan materi untuk siswa reguler. Penyederhanaan bobot soal di kelas III ini dilakukan ketika siswa slow learner tidak dapat menyelesaikan soal dengan bobot yang sama dengan siswa reguler. Pada saat menjelaskan materi di kelas, guru menggunakan metode ceramah dan disampaikan secara klasikal. Setelah selesai menjelaskan, guru kelas III selalu 
bertanya kepada siswa apakah ada yang masih belum memahami penjelasan dari guru. Jika ada siswa yang belum paham, guru kelas III biasanya akan menjelaskan ulang secara klasikal, maupun individual. ${ }^{18}$

Pada pembelajaran di kelas IV dan V, guru kelas juga melakukan strategi pembelajaran dengan tutor teman sebaya, seperti yang dilakukan oleh guru kelas III. Namun, untuk kelas IV dan V, guru lebih sering melakukan pembelajaran kooperatif dengan membentuk kelompok belajar. Pembentukan kelompok belajar ini dinilai guru kelas cukup efektif untuk membuat siswa slow learner cepat dalam memahami suatu materi. Dalam pembentukan kelompok belajar, guru kelas IV dan V selalu membentuk kelompok yang heterogen, yang beranggotakan siswa reguler dan slow learner. Pembentukan kelompok yang heterogen diharapkan agar siswa dapat saling membantu satu sama lain dalam kelompok. Selain itu, pembentukan kelompok yang heterogen juga bertujuan agar siswa slow learner merasa dipercaya oleh guru untuk memecahkan masalah bersama teman-temannya yang lain sehingga dapat menambah rasa percaya diri mereka.

Setelah adanya diskusi dalam kelompok-kelompok belajar, guru kelas juga meminta siswa untuk mempresentasikan hasil diskusi di depan kelas. Guru kelas IV dan V juga biasa meminta siswa slow learner untuk membacakan hasil diskusi di depan teman-temannya di kelas. Hal tersebut dilakukan oleh guru agar siswa slow learner mempunyai rasa percaya diri yang kuat juga menumbuhkan keberanian dalam diri siswa. Dengan diajak diskusi dan presentasi, siswa lebih terfokus pada jalannya proses pembelajaran dibandingkan jiak guru hanya menggunakan metode ceramah di depan kelas.

Selanjutnya, cara yang ditempuh semua guru kelas dalam menyampaikan pokok-pokok materi dan penjelasannya untuk anak slow learner dama dengan penyampaian pokok-pokok materi dan penjelasannya untuk siswa lain. Kelima guru kelas menyampaikan pokok materi melalui ceramah dan secara klasikal di depan kelas. Kemudian dilanjutkan dengan tanya jawab secara lisan dengan semua siswa. Untuk pelajaran matematika, guru kelas memberi contoh di papan tulis dan menjelaskan setahap demi setahap kepada siswa. Lalu guru memberikan soal entah berupa soal yang ditulis di papan tulis maupun soal yang terdapat dalam buku teks. Guru juga membimbing siswa dalam mengerjakan tahapan-tahapan pengerjaan soal jika siswa menemui kesulitan.

18. Hasil observasi di Kelas III SD N Bangunrejo 2 Yogyakarta pada 11 Mei 2018. 
Biasanya, dalam pengerjaan soal, siswa normal akan lebih cepat dalam mengerjakan. Hal tersebut dimanfaatkan oleh guru kelas untuk membantu mengajari anak slow learner. Siswa yang sudah bisa dan sudah selesai mengerjakan akan diminta oleh guru kelas untuk membimbing dan mengajari anak slow learner yang masih mengalami kesulitan dalam mengerjakan soal. Berbeda hal nya dengan guru kelas II. Saat pembelajaran matematika berlangsung, guru tersebut hanya memberikan contoh di awal kemudian meminta siswa mengerjakan soal. ${ }^{19}$

Soal yang diberikann utnuk dikerjakan diberikan secara lisan, tanpa ada bimbingan khusus untuk anak slow learner. Dengan demikian, anak normal yang bisa mengikuti akan lebih cepat mengerjakan. Sedangkan anak slow learner mengalami ketertinggalan yang cukup jauh. Guru kelas tidak memberikan bimbingan khusus karena menganggap anak-anak di kelasnya mudah lupa dan mudah terpecah fokus ketika diberikan bimbingan saat itu juga. Biasanya guru tersebut memberikan tambahan waktu kepada anak slow learner. Jadi, setelah siswa lain selesai mengerjakan, guru meminta mereka istirahat di luar kelas sehingga beliau bisa memberikan bimbingan khusus kepada anak slow learner.

Dalam kegiatan tanya jawab, anak slow learner cenderung pasif. Namun, guru tidak memberikan perlakuan khusus pada anak slow learner. Guru memberikan kesempatan yang sama kepada semua siswa untuk bertanya. Anak slow learner biasanya menanyakan seputar instruksi yang diberikan oleh guru. Untuk beberapa anak slow learner yang benar-benar "slow" guru akan mendatangi satu persatu dan menanyakan secara individual tentang mareri yang belum dipahami. Selain itu, setiap selesai menjelaskan, guru selalu menanyakan kembali apakah ada siswa yang masih belum paham dan ingin bertanya. Para guru menanamkan kepada siswa untuk selalu bertanya jika ada yang belum dipahami, baik itu bertanya pada guru maupun pada siswa yang lebih bisa.

Seperti halnya dalam penyampaian pokok materi dan penjelasannya, cara yang ditempuh guru kelas dalam memberikan contoh dan noncontoh pada anak slow learner sama dengan siswa lainnya. Perlakuan khusus untuk anak slow learner tidak diberikan pada aspek contoh dan non contoh. Ketiga guru kelas memberikan contoh dan noncontoh dalam menjelaskan pokok materi melalui penjelasan secara lisan dan klasikal, disertai tanya jawab.

19. Hasil observasi di Kelas II SD N Bangunrejo 2 Yogyakarta pada 15 Mei 2018. 
Melalui tanya jawab, guru dapat mengetahui sejauh mana pemahaman siswa tentang materi yang sudah dijelaskan. Ketika siswa sudah dapat menjawab pertanyaan dan menyebutkan contoh yang ditanya oleh guru, siswa dianggap sudah memahami materu yang disampaikan. Namun jika siswa belum dapat menyebutkan contoh dengan benar maka siswa dianggap belum menguasai pokok materi yang sudah dijelaskan.

Selain itu, guru juga tidak selalu menggunakan media pembelajaran atau alat peraga dalam memberikan contoh. Secara umum, media pembelajaran dan alat peraga yang digunakan untuk anak slow learner sama dengan siswa lainnya. Media pembelajaran atau alat peraga yang digunakan guru bervariasi, menyesuaikan dengan materi dan tujuan pembelajaran. Media pembelajaran atau alat peraga yang digunakan biasanya berupa alat peraga berbentuk visal dalam bentuk gambar atau benda konkret yang dapat dijumpai di lingkungan sekitar siswa.

Walaupun tidak selalu menggunakan media pembelajaran atau alat peraga, namun guru selalu memberikan contoh dengan mengaitkan materi dengan kehidupan sehari-hari siswa. Pemberian contoh yang dikaitkan dengan kehidupan sehari-hari siswa dimaksudkan agar siswa lebih mudah mengerti dan mengingat contoh yang diberikan oleh guru.

Pada proses pembelajaran yang berlangsung di kelas, guru kelas belum nampak secara langsung membahas kembali materi yang belum dikuasai siswa, khususnya siswa slow learner pada saat proses pembelajaran dikarenakan alokasi waktu yang terbatas. Guru biasanya akan membahas kembali materi pelajaran yang belum dikuasai oleh siswa slow learner jika siswa tersebut bertanya. Namun, tidak semua siswa slow learner mau bertanya. Hanya ada beberapa anak yang ketika sudah diberikan penjelasan dan tidak bisa ketika mengerjakan soal baru mau bertanya kepada guru kelas. Akan tetapi, masih banyak juga siswa slow learner yang ketika tidak bisa mengerjakan soal, tetap tidak bertanya.

Guru kelas I dan II masih memberikan waktu khusus bagi siswa slow learner untuk belajar lagi, mengulang yang sudah dipelajari saat jam istirahat maupun jam pulang sekolah. Untuk siswa slow learner di kelas I, guru lebih cenderung memberikan tambahan waktu untuk drill latihan membaca. Guru kelas II memberi bimbingan khusus untuk mengerjakan latihan soal terutama matematika di mana ketika berada di kelas, siswa slow learner selalu tertinggal dengan siswa lain. Sedangkan untuk siswa kelas III hingga kelas V, guru lebih 
memberikan penguilangan materi ketika diadakannya remidial. Sebelum remidial dilangsungkan, gutu akan membahas kembali materi yang belum dikuasai siswa.

Selama proses pembelajaran, guru kelas juga memberikan latihan-latihan soal rutin untuk semua siswa, termasuk siswa slow learner. Dalam hal memberikan latihan, guru kelas 1 menjelaskan bahwa jika latihan yang diberikan saat jam pelajaran dirasa kurang, maka guru akan memberikan tambahan latihan, berupa pekerjaan rumah.

Latihan soal yang diberikan kepada siswa slow learner sama dengan siswa lain. Hal ini dilakukan agar siswa slow learner merasa diperlakukan sama dengan siswa lain. Namun jika nanti setelah pemberian latihan ternyata anak slow learner tidak bisa mencapai tujuan yang sama dengan siswa lain, guru akan memberikan perbaikan dengan menurunkan bobot angka soal. Ketika anak slow learner sudah menguasai latihan yang diberikan, maka guru akan memberikan soal dengan bobot yang lebih.

Hal kedua yang perlu diperhatikan guru kelas dalam memberikan latihan dan praktik adalah tambahan alokasi waktu yang diberikan untuk anak slow learner. Kelima guru kelas memberikan tambahan waktu untuk anak slow learner. Guru kelas memberikan tambahan waktu untuk anak slow learner dan siswa yang belum selesai mengerjakan latihan di kelas. Namun biasanya siswa yang sering mendapat tambahan waktu adalah anak slow learner.

Tambahan waktu diberikan dalam kegiatan pembelajaran setiap harinya. Namun jika dirasa tambahan waktu yang diberikan masih belum cukup, guru kelas akan meminta siswa untuk melanjutkan di rumah atau dilanjutkan pada pertemuan selanjutnya.

Berbeda dengan ketika berlangsungnya Ujian Tengah Semester atau Ujian Akhir Semester, guru kelas 3 sampai kelas 5 tidak memberikan tambahan waktu dalam pengerjaan soal. Nantinya, jika nilai anak masih belum mencapai tujuan yang ditetapkan, guru akan memberikan bimbingan dan perbaikan. Namun untuk anak slow learner yang masih duduk di kelas 1 dan 2, guru memberikan toleransi tambahan waktu sebesar 30 menit. Guru kelas 3 sampai 5 tidak memberikan tambahan waktu untuk anak slow learner ketika ujian berlangsung karena menganggap anak sudah lebih mampu dibanding ketika masih duduk di kelas 1 atau 2. 
4. Penggunaan Media Pembelajaran

Dalam penyampaian materi, kelima guru kelas tidak selalu menggunakan media pembelajaran atau alat peraga. Guru kelas I-V di SD N Bangunrejo 2 bahkan sangat jarang menggunakan media komputer atau animasi saat proses pembelajaran berlangsung. Hal tersebut dikarenakan sarana di sekolah yang kurang memadai. Namun ada beberapa guru seperti guru kelas II dan guru kelas IV yang menggunakan laptop pribadi untuk kebutuhan pembelajaran. Media pembelajaran yang digunakan oleh semua guru dibuat sama untuk semua siswa, baik itu siswa reguler maupun siswa slow learner.

Dikarenakan tidak adanya sarana seperti komputer atau lcd di sekolah, maka guru dituntut kreatif membuat media pembelajaran. Jika pembelajaran yang akan dilaksanakan dirasa memerlukan media, maka guru kelas akan mengusahakannya.

Keefektifan penggunaan media pembelajaran dan alat peraga ditiap kelas berbeda-beda. Seperti di kelas V, siswa di kelas V senang ketika menggunakan alat peraga seperti poster atau gambar-gambar, dan hal tersebut efektif dalam membuar anak slow learner mengingat materi yang disampaikan. Namun untuk kelas lain, adanya media pembelajaran tidak sepenuhnya efektif karena guru masih harus mengulang-ulang materi agar anak menjadi ingat dan memahami materi pembelajaran yang disampaikan.

\section{H. KESIMPULAN}

Berdasarkan penelitian yang telah dilakukan, dapat disimpulkan bahwa:

1. Mofidikasi alokasi waktu

Semua guru kelas melakukan modifikasi berupa penambahan waktu. Namun, strategi tiap guru kelas dalam memberikan modifikasi alokasi waktu berbedabeda. Guru kelas I memberi penambahan waktu selama proses pembelajaran dan juga ketika ulangan harian maupun ujian akhir. Sedangkan untuk guru kelas II, modifikasi alokasi waktu yang diberikan berupa penambahan jam ketika di luar jam pelajaran. Biasanya diberikan ketika jam istirahat maupun saat jam pulang sekolah. Selanjutnya untuk siswa kelas atas, yaitu siswa kelas III, IV, dan V, guru hampir tidak melakukan modifikasi alokasi waktu. Namun untuk guru kelas III terkadang masing memberi tambahan waktu sebesar 5-10 menit kepada siswa. 
2. Modifikasi isi atau materi

Kelima guru kelas melakukan modifikasi berupa penggunaan penurunan bobot soal. Misalkan untuk siswa reguler angka yang dipelajari adalah 100-1000 maka untuk siswa slow learner hanya 10-100. Selain itu, jika ada kalimat atau kata yang sulit, guru akan menerjemahkannya kembali dalam bahasa yang lebih sederhana, bahkan terkadang menggunakan bahasa jawa.

3. Modifikasi proses belajar mengajar

Untuk siswa slow learner di kelas I, guru lebih menekankan pada latihan membaca setiap hari. Untuk siswa kelas II, guru kelas justru meninggalkan siswa slow learner saat proses pembelajaran agar siswa reguler tidak tertinggal. Namun, saat jam istirahat dan jam pulang sekolah, guru kelas II memberikan jam tambahan khusus bagi siswa slow learner tersebut. Sedangkan untuk siswa kelas III, guru kelas memberikan perlakuan yang sama untuk siswa slow learner dan siswa reguler selama proses pembelajaran. Namun guru akan memberi kesempatan kepada siswa untuk bertanya ulang kepada siswa jika ada yang masih belum mengerti. Dalam pelaksanannya, banyak siswa kelas III yang ketika belum mengerti mereka akan bertanya langsung pada guru dengan maju ke meja guru. Selain itu, guru kelas III juga sudah mulai menerapkan strategi tutor teman sebaya selama proses pembelajaran.

Modifikasi pembelajaran yang sangat terlihat ada di kelas IV dan V. Di mana guru di kelas tersebut menerapkan pembelajaran kooperatif dengan membentuk kelompok-kelompok belajar. Hal tersebut dilakukan guru karena dianggap efektif untuk membuat siswa slow learner mudah dalam mengingat dan memahami materi yang disampaikan.

4. Penggunaan media pembelajaran

Kondisi sarana dan prasarana di sekolah yang kurang memadai menyebabkan guru dituntut untuk aktif membuat media pembelajaran. Penggunaan media pembelajaran disesuaikan dengan materi dan kebutuhan siswa. Media yang digunakan dibuat sama untuk siswa reguler dan juga siswa slow learner. Namun, penggunaan media pembelajaran tidak sepenuhnya berjalan efektif. 


\section{DAFTAR PUSTAKA}

Apriyanto, Nunung. Seluk Beluk Tunagrahita dan Strategi Pembelajarannya. Yogyakarta: Javalitera, 2012.

dkk, Abdul. Pendidikan Anak Berkebutuhan Khusus Secara Inklusif. Surakarta: Universitas Sebelas Maret, 2009.

G, Lokanadha Reddy. Slow Learner: Their Psychology and Instruction. New Delhi: Discovery Publishing House, 2006.

Khabibah, Nur. "Penanganan Instruksional Bagi Anak Lambat Belajar (Slow Learner)." Jurnal Didaktika Vol. 19, no. 2 (Februari 2013).

Khayati, Abdiyatun. "Layanan Pendidikan Bagi Siswa Slow Learner Oleh Guru di Kelas III.” Jurnal Pendidikan Guru Sekolah Dasar, Tahun ke-5, 2016.

Sehmawati. "Kajian Program KB 2 Anak Cukup terhadap Nilai Anak dengan Keinginan Wanita Menambah Anak." Jurnak Kesehatan Ibu dan Anak Vol. 1, no. 1 (Desember 2006).

Sugihartono. Psikologi Pendidikan. Yogyakarta: UNY Press, 2007.

T, Sutjihati Soemantri. Psikologi Anak Luar Biasa. Bandung: PT. Refika Aditama, 2006.

UUSPN Pasal 5 ayat 2. 